\title{
Soil Nitrogen and Sulfur Leaching in a Subtropical Forest at a Transition State under Decreasing Atmospheric Deposition
}

\author{
Piaopiao Ke ${ }^{1} \mathbb{D}$, Gaoyue Si $^{2}$, Yao Luo ${ }^{1}$, Zhenglin Cheng ${ }^{1}$, Qian Yu ${ }^{1, *}$ and Lei Duan ${ }^{1}$ \\ 1 State Key Laboratory of Environmental Simulation and Pollution Control, School of Environment, \\ Tsinghua University, Beijing 100084, China; kpp17@mails.tsinghua.edu.cn (P.K.); luoy.x12@gmail.com (Y.L.); \\ chengz1103@126.com (Z.C.); lduan@tsinghua.edu.cn (L.D.) \\ 2 School of Agriculture and Biology, Shanghai Jiaotong University, Shanghai 200240, China; gaoyuesi@163.com \\ * Correspondence: yuqiang_cha78@163.com
}

Citation: Ke, P.; Si, G.; Luo, Y.; Cheng, Z.; Yu, Q.; Duan, L. Soil Nitrogen and Sulfur Leaching in a Subtropical Forest at a Transition State under Decreasing Atmospheric Deposition. Forests 2021, 12, 1798. https://doi.org/10.3390/f12121798

Academic Editors: Xiankai Lu and Timothy A. Martin

Received: 20 October 2021

Accepted: 16 December 2021

Published: 17 December 2021

Publisher's Note: MDPI stays neutral with regard to jurisdictional claims in published maps and institutional affiliations.

Copyright: (c) 2021 by the authors. Licensee MDPI, Basel, Switzerland. This article is an open access article distributed under the terms and conditions of the Creative Commons Attribution (CC BY) license (https:// creativecommons.org/licenses/by/ $4.0 /)$.

\begin{abstract}
Anthropogenic emissions of nitrogen- (N) and sulfur (S)-containing pollutants have declined across $\mathrm{China}$ in recent years. However, the responses of $\mathrm{N}$ and $\mathrm{S}$ depositions and dynamics in soil remain unclear in subtropical forests. In this study, the wet and throughfall depositions of dissolved inorganic $\mathrm{N}$ (DIN) and $\mathrm{SO}_{4}{ }^{2-}$ were continuously monitored in a mildly polluted subtropical forest in Southeast China in 2017 and 2018. Moreover, these solutes in soil water along the soil profile were monitored in 2018. Throughfall deposition of DIN and S decreased by $59 \%$ and $53 \%$ in recent 3 years, respectively, which can be majorly attributed to the decreases in wet depositions of $\mathrm{NO}_{3}{ }^{-}$and $\mathrm{SO}_{4}{ }^{2-}$. Meanwhile, $\mathrm{NH}_{4}{ }^{+}$deposition remained relatively stable at this site. Even though $\mathrm{N}$ deposition in 2018 was below the $\mathrm{N}$ saturation threshold for subtropical forests, significant $\mathrm{N}$ leaching still occurred. Excess export of $\mathrm{N}$ occurred in the upper soil layer $(0-15 \mathrm{~cm})$, reaching $6.86 \pm 1.54 \mathrm{~kg} \mathrm{~N} / \mathrm{ha} / \mathrm{yr}$, while the deeper soil $(15-30 \mathrm{~cm})$ was net sink of $\mathrm{N}$ as $8.29 \pm 1.71 \mathrm{~kg} \mathrm{~N} / \mathrm{ha} / \mathrm{yr}$. Similarly, S was excessively exported from the upper soil with net flux of $14.7 \pm 3.15 \mathrm{~kg} \mathrm{~S} / \mathrm{ha} / \mathrm{yr}$, while up to $6.37 \pm 3.18 \mathrm{~kg} \mathrm{~S} / \mathrm{ha} / \mathrm{yr}$ of $\mathrm{S}$ was retained in the deeper soil. The significant $\mathrm{N}$ and $\mathrm{S}$ leaching under declined depositions suggested that this site possibly underwent a transition state, recovering from historically high acid deposition. Furthermore, the rainfall intensity remarkably regulated leaching and retention of $\mathrm{SO}_{4}{ }^{2-}$ and DIN at this site. The impacts of climate changes on $\mathrm{N}$ and $\mathrm{S}$ dynamics require further long-term monitoring in subtropical forests.
\end{abstract}

Keywords: acid deposition; acidification; input-output budget; sulfate adsorption; nitrogen mineralization; retention

\section{Introduction}

Elevated nitrogen $(\mathrm{N})$ and sulfur $(\mathrm{S})$ depositions have been widely reported to cause acidification and eutrophication in terrestrial ecosystems, influencing nutrient balance, vegetation growth, and biodiversity in Europe [1,2] and North America [3] in 1970s, and in East Asia in around a decade later [4]. Nitrogen deposition could act as an external N supply and improve ecosystem productivity if total biotic $\mathrm{N}$ demands in the ecosystems are not exceeded. However, excel $\mathrm{N}$ input would lead $\mathrm{N}$ saturation, indicated by significant $\mathrm{N}$ leaching from soil [5]. Enhanced atmospheric $\mathrm{S}$ and $\mathrm{N}$ depositions resulted primarily from increased anthropogenic emissions of sulfur dioxides $\left(\mathrm{SO}_{2}\right)$, nitrogen oxides $\left(\mathrm{NO}_{\mathrm{x}}\right)$, and ammonia $\left(\mathrm{NH}_{3}\right)$ [4]. Following dramatic economic development since the 1970s, the anthropogenic emissions of these air pollutants rapidly increased in China [4]. The concomitant high loads of $\mathrm{N}$ and $\mathrm{S}$ to forests have caused significant soil acidification, especially in South China, where the forest soils are susceptible to acid deposition [6,7].

Due to successful implementations of pollution control policies in China, $\mathrm{SO}_{2}$ and $\mathrm{NO}_{\mathrm{x}}$ emissions have significantly declined since 2006 and 2011, respectively [8,9], while total $\mathrm{NH}_{3}$ emissions have remained relatively stable [9]. It has been suggested that $\mathrm{N}$ and $\mathrm{S}$ depositions generally decreased across China in recent years $[6,8,10,11]$. However, the actual 
status of $\mathrm{N}$ and $\mathrm{S}$ depositions and responses of subtropical forest soils are not completely understood. To date, long-term field investigations of $\mathrm{N}$ and $\mathrm{S}$ depositions in subtropical forests are scarce, and even fewer studies have monitored $\mathrm{N}$ and $\mathrm{S}$ dynamics in soil, as most studies have focused on the impacts of $\mathrm{N}$ addition in forest ecosystems [12,13]. Generally, $\mathrm{NO}_{3}{ }^{-}$concentration in soil water and $\mathrm{N}$ leaching respond more rapidly than soil organic matter and wood to changes in atmospheric $\mathrm{N}$ deposition [13-15]. A sharp decline in $\mathrm{N}$ deposition has led to an instantaneous reduction in $\mathrm{N}$ leaching and soil mineralization and immobilization rates in a heavily N-polluted subtropical forest in Southwest China $[13,16]$. Nevertheless, changes in $\mathrm{N}$ leaching from soil at this site did not follow the hysteretic model proposed to predict the responses of temperate forests to declined N deposition [15]. The $\mathrm{SO}_{4}{ }^{2-}$ leaching decreased concomitantly with $\mathrm{S}$ deposition $(180 \mathrm{~kg} \mathrm{~S} / \mathrm{ha} / \mathrm{yr})$ and net accumulation of $\mathrm{SO}_{4}{ }^{2-}$ in soil continued to occur in this forest [8,17]. In contrast, longterm monitoring in Europe and North America indicated excess S export from temperate forest soils under low atmospheric $\mathrm{SO}_{4}{ }^{2-}$ deposition $(<16 \mathrm{~kg} \mathrm{~S} / \mathrm{ha} / \mathrm{yr})[1,2,18]$, which can possibly be attributed to the historic accumulation of $S$ in soil, e.g., the desorption of $\mathrm{SO}_{4}{ }^{2-}$ and mineralization of organic $\mathrm{S}$ [19]. Net release of $\mathrm{SO}_{4}{ }^{2-}$ may delay the recovery of forest ecosystems from acidification if it is caused by the legacy effects of historic $S$ deposition $[1,2,4,18,20]$. Regarding the spatial variation of atmospheric $\mathrm{N}$ and $\mathrm{S}$ depositions $[13,21]$, more field investigations in subtropical forests are required to understand the status of $\mathrm{N}$ and $\mathrm{S}$ depositions and the corresponding responses of subtropical forest soil.

So far, the responses of subtropical forests to declined $\mathrm{N}$ and $\mathrm{S}$ depositions in China have only been investigated in a forest that still receives high inputs of $\mathrm{N}$ and $\mathrm{S}$. How less polluted subtropical forests in China respond to the declined depositions remains unknown, to our knowledge. In this study, a mildly polluted subtropical forest in Southeast China was revisited in 2017 and 2018 and temporal characteristics of the dissolved inorganic nitrogen (DIN, represented as sum of $\mathrm{NO}_{3}{ }^{-}$and $\mathrm{NH}_{4}{ }^{+}$) and $\mathrm{SO}_{4}{ }^{2-}$ depositions via precipitation and throughfall were investigated. In addition, the dynamics of $\mathrm{NO}_{3}{ }^{-}, \mathrm{NH}_{4}{ }^{+}$, and $\mathrm{SO}_{4}{ }^{2-}$ in soil water along the soil profile were monitored in 2018. The $\mathrm{N}$ and $\mathrm{S}$ budgets in the surface soil $(0-30 \mathrm{~cm})$, where most interactions between vegetation, soil, and microbes occurred, were established and compared with previous monitoring [22] to demonstrate the responses of this forest to the decreased depositions.

\section{Materials and Methods}

\subsection{Site Description}

The field investigation in this study was carried out in Qianyanzhou Ecological Station (QYZ, $115^{\circ} 4^{\prime} \mathrm{E}, 26^{\circ} 45^{\prime} \mathrm{N}$, managed by the Chinese Academy of Sciences) from February 2017 to April 2019. This site is located in Jiangxi Province and is under a subtropical monsoon climate, with major rainfall events appearing between March and September [23]. The mean annual precipitation and temperature are $1494 \mathrm{~mm}$ and $19.2^{\circ} \mathrm{C}$ [24], respectively. Furthermore, this site is approximately $42 \mathrm{~km}$ southeast of the nearest city, Ji'an City, and there are no significant industrial plants or coal burning boilers within $\sim 30 \mathrm{~km}$ [25]. The predominant wind direction is southeast in the summer and northwest in the winter [26]. The forest is Pinus massoniana predominated, with approximately 17 ha in area, and surrounded by agricultural fields [26]. The stand age of the pine trees is around 35 years and the canopy height is about $16 \mathrm{~m}$ [27]. The major soil type is red earth, highly weathered from red sand rock, and the soil $\mathrm{pH}$ is 4.6 [28]. The fine roots are concentrated at 0-20 cm depth, with approximately $63 \%$ at $0-10 \mathrm{~cm}$ depth $[29,30]$. This site received $19.9 \mathrm{~kg}$ $\mathrm{N} / \mathrm{ha} / \mathrm{yr}$ and $27.8 \mathrm{~kg} \mathrm{~S} / \mathrm{ha} / \mathrm{yr}$ in precipitations in 2014 [9], which were both at lower levels of corresponding depositions across subtropical forests in China, ranging $18.2-88.2 \mathrm{~kg}$ $\mathrm{N} / \mathrm{ha} / \mathrm{yr}$ and 4.8-144 $\mathrm{kg} \mathrm{S} / \mathrm{ha} / \mathrm{yr}$ for $\mathrm{N}$ and $\mathrm{S}$, respectively [10,31,32]. Hence, this site could be considered as a mildly polluted site in South China [25]. 


\subsection{Sampling and Chemical Analysis}

A total of three $10 \mathrm{~m} \times 10 \mathrm{~m}$ plots were randomly set up under the forest canopy, with two throughfall collectors (at the nonadjacent corners) and two sets of soil water lysimeters near the center in each plot. The throughfall collector consisted of an $8.6 \mathrm{~cm}$ diameter funnel, covered with nylon gauze to prevent entrances of litterfall and insects, and an opaque $3 \mathrm{~L}$ bottle to store water [25]. Another six sets of collectors were installed in open areas for bulk precipitation sampling. Soil water samples at $5 \mathrm{~cm}$ depth (S5, topsoil), $15 \mathrm{~cm}$ depth (S15, in the root zone), and $30 \mathrm{~cm}$ depth (S30, below the root zone) were collected through Rhizon lysimeters (Eijkelkamp, Wageningen, The Netherlands). The bulk precipitation, throughfall, and soil water were sampled weekly and then quickly stored at $4{ }^{\circ} \mathrm{C}$ in a refrigerator. The weekly samples in the month were lumped together for subsequent chemical analysis. All the monthly mixed water samples were filtered through $0.45 \mu \mathrm{m}$ syringe filters and then analyzed for cation and anion concentrations by ion chromatography (ICS-2000, Dionex Corp., Sunnyvale, CA, USA). Detailed sampling and chemical analysis method can be seen in Refs. $[16,17,33]$. Since humus layer accumulates on the topsoil, solute fluxes in soil water at S5 were considered as total fluxes from the organic layer and topsoil.

\subsection{Data Processing}

Monthly fluxes in precipitation, throughfall, and soil water along the soil profile were calculated as ion concentration multiplied by the corresponding water fluxes. Mean values of the three plots were applied to represent the monthly depositions and solute fluxes in the soil water at this site. For soil solution, where direct measurements of the water fluxes do not exist [21], the water fluxes were estimated based on $\mathrm{Na}^{+}$balance according to the conservativeness of $\mathrm{Na}^{+}$in soil water [17]. However, the mineral weathering and potential cation exchange might induce uncertainties to the estimation of soil water fluxes, particularly in deeper soil [8]. In this study, the flux of soil water at S30 was approximated as stream water flux in this region [21,22], as the evapotranspiration below the root zone could possibly be minor. The seasonal correlations between stream water fluxes and precipitations was applied based on hydrological researches in this region [22,34]. Since the stream water flux was not measured in this study, there was inevitable uncertainty of the soil water flux calculation at S30. However, the seasonal pattern of rainfall in the previous monitoring was similar to that this study [34] and the correlations may still be applicable to this study. The accumulative fluxes in the seasons and years were attained by directly adding up monthly fluxes, while seasonal and annual concentrations were volume-weighted averages. Detailed formulation could be seen in Ref. [25]. The enhanced deposition from precipitation to throughfall was attributed to dry deposition, while the decreased concentrations and deposition were likely due to the overriding process of canopy interception $[26,35,36]$. During the transformation between $\mathrm{NH}_{4}{ }^{+}$and $\mathrm{NO}_{3}{ }^{-}$in soil, $\mathrm{H}^{+}$could be generated $\left(\mathrm{H}^{+}\right.$prod, $\left.\mathrm{N}\right)$ and induce soil acidification $[17,37]$, as follows:

$$
\mathrm{H}^{+} \text {prod, } \mathrm{N}=\left(\mathrm{NH}_{4}{ }^{+}{ }_{\mathrm{i}}-\mathrm{NH}_{4}{ }^{+}{ }_{\mathrm{o}}\right)+\left(\mathrm{NO}_{3}{ }^{-} \mathrm{o}^{-}-\mathrm{NO}_{3}{ }^{-}{ }_{\mathrm{i}}\right)
$$

where $\mathrm{NH}_{4}{ }^{+}$and $\mathrm{NO}_{3}{ }^{-}{ }_{i}$ are input fluxes of $\mathrm{NH}_{4}{ }^{+}$and $\mathrm{NO}_{3}{ }^{-}$, respectively, and $\mathrm{NH}_{4}{ }^{+}$o and $\mathrm{NO}_{3}{ }^{-}$o are the leaching fluxes of $\mathrm{NH}_{4}{ }^{+}$and $\mathrm{NO}_{3}{ }^{-}$, respectively.

Due to sampling problems, the soil water collections stopped from August 2017 to March 2018. Hence, only data of depositions and soil solution fluxes in 2018 were discussed in detail in this study. Results in 2017 can be seen in Figures A1 and A2. All the graph drawing and the correlation analysis were conducted in OriginPro 2021.

\section{Results and Discussion}

\subsection{Seasonal DIN and S Concentrations and Fluxes}

The annual water flux of throughfall in 2018 was $1097 \mathrm{~mm}, 3.8 \%$ smaller than the precipitation (Figure 1), while the annual soil water flux below the root zone accounted 
for $57.0 \%$ of the throughfall. Annual mean concentrations of $\mathrm{SO}_{4}{ }^{2-}, \mathrm{NH}_{4}{ }^{+}$, and $\mathrm{NO}_{3}{ }^{-}$in precipitations were $2.84 \pm 0.67,0.833 \pm 0.056$, and $1.31 \pm 0.11 \mathrm{mg} / \mathrm{L}$, respectively. Generally, higher ion concentrations were observed in throughfall than those in precipitations in each season, except in the spring, when $\mathrm{NH}_{4}{ }^{+}$concentration in throughfall decreased by $3 \%$ from precipitation. Highest concentrations of $\mathrm{SO}_{4}{ }^{2-}, \mathrm{NO}_{3}{ }^{-}$, and $\mathrm{NH}_{4}{ }^{+}$in precipitation and throughfall were mostly observed in the autumn or winter, when the water fluxes were smallest (Figures 1 and A1). The ratio between $\mathrm{NH}_{4}{ }^{+}$and $\mathrm{NO}_{3}{ }^{-}$concentrations decreased from bulk precipitation (1.86-2.49) to throughfall (1.37-2.48), except in the summer. The seasonal variation of $\mathrm{N}$ concentration in precipitation was similar to the observation at this site during 2014 and 2015 [22,25]. From throughfall to soil water within depth of $15 \mathrm{~cm}, \mathrm{SO}_{4}{ }^{2-}$ and $\mathrm{NO}_{3}{ }^{-}$concentrations increased gradually (Figure 1). From $15 \mathrm{~cm}$ to $30 \mathrm{~cm}$, however, the concentrations decreased, except in the autumn. Generally, the concentrations of $\mathrm{SO}_{4}{ }^{2-}, \mathrm{NH}_{4}{ }^{+}$, and $\mathrm{NO}_{3}{ }^{-}$in the precipitation, throughfall, and soil water were negatively correlated with the corresponding water fluxes $(p<0.1)$. For $\mathrm{NH}_{4}{ }^{+}$, the concentration decreased sharply from throughfall to soil waters. The ratio between $\mathrm{NH}_{4}{ }^{+}$and $\mathrm{NO}_{3}{ }^{-}$concentrations ranged from 0.06 to 0.55 in these three layers of soil.

The annual fluxes of $\mathrm{SO}_{4}{ }^{2-}$ and DIN via precipitation in 2018 were $10.8 \pm 0.6 \mathrm{~kg} \mathrm{~S} / \mathrm{ha} / \mathrm{yr}$ and $10.8 \pm 0.22 \mathrm{~kg} \mathrm{~N} / \mathrm{ha} / \mathrm{yr}$, respectively. The highest $\mathrm{SO}_{4}{ }^{2-}$ flux in throughfall occurred in the spring, while the maximum throughfall deposition of DIN occurred in the summer (Figure 1). Dry deposition of $S$ and oxidized $N$ peaked in the spring, while the highest dry deposition of reduced $\mathrm{N}$ appeared in the summer. Meanwhile, significant canopy interception of $\mathrm{NH}_{4}{ }^{+}$occurred in the spring (in 2017) and summer (in 2018), accounting for $19 \%$ and $7 \%$ of the wet deposition, respectively (Figure 1). For $\mathrm{NO}_{3}{ }^{-}$, the significant canopy interception appeared in the autumn of 2017, accounting for $11 \%$ of the wet deposition (Figure A2). The observed interception rate of $\mathrm{NO}_{3}{ }^{-}$in the autumn was comparable to that previously reported for Pinus massoniana-predominated forests in this region in the winter [36]. Wet surface of the forest canopy and vegetation demands of $\mathrm{N}$ could facilitate canopy interceptions of nutrients [35,36]. In other seasons, dry deposition of $\mathrm{N}$ might override the canopy $\mathrm{N}$ interception, leading to increased concentrations and depositions from precipitation to throughfall.

The annual leaching of $\mathrm{SO}_{4}{ }^{2-}$ and DIN (majorly $\mathrm{NO}_{3}{ }^{-}$in soil waters) from the root zone reached $24.3 \pm 0.94 \mathrm{~kg} \mathrm{~S} / \mathrm{ha} / \mathrm{yr}$ and $12.6 \pm 0.092 \mathrm{~kg} \mathrm{~N} / \mathrm{ha} / \mathrm{yr}$, respectively. In each season, the $\mathrm{NH}_{4}{ }^{+}$flux decreased sharply from throughfall to the S5 layer, and further decreased gradually along the soil profile. Although the DIN flux in the S30 layer was smaller than the throughfall deposition, the S5 and S15 layers had relatively larger fluxes than the throughfall deposition. The $\mathrm{SO}_{4}{ }^{2-}$ flux from the root zone was larger than the throughfall deposition, except in the autumn. Notably, $\mathrm{SO}_{4}{ }^{2-}$ and DIN leaching in the S30 layer were always smaller than the leaching in the upper layer. Moreover, the leaching of $\mathrm{SO}_{4}{ }^{2-}$ from the soil significantly increased at $5-15 \mathrm{~cm}$ depth in the spring and summer, on the contrary to the autumn and winter (Figure 1). 


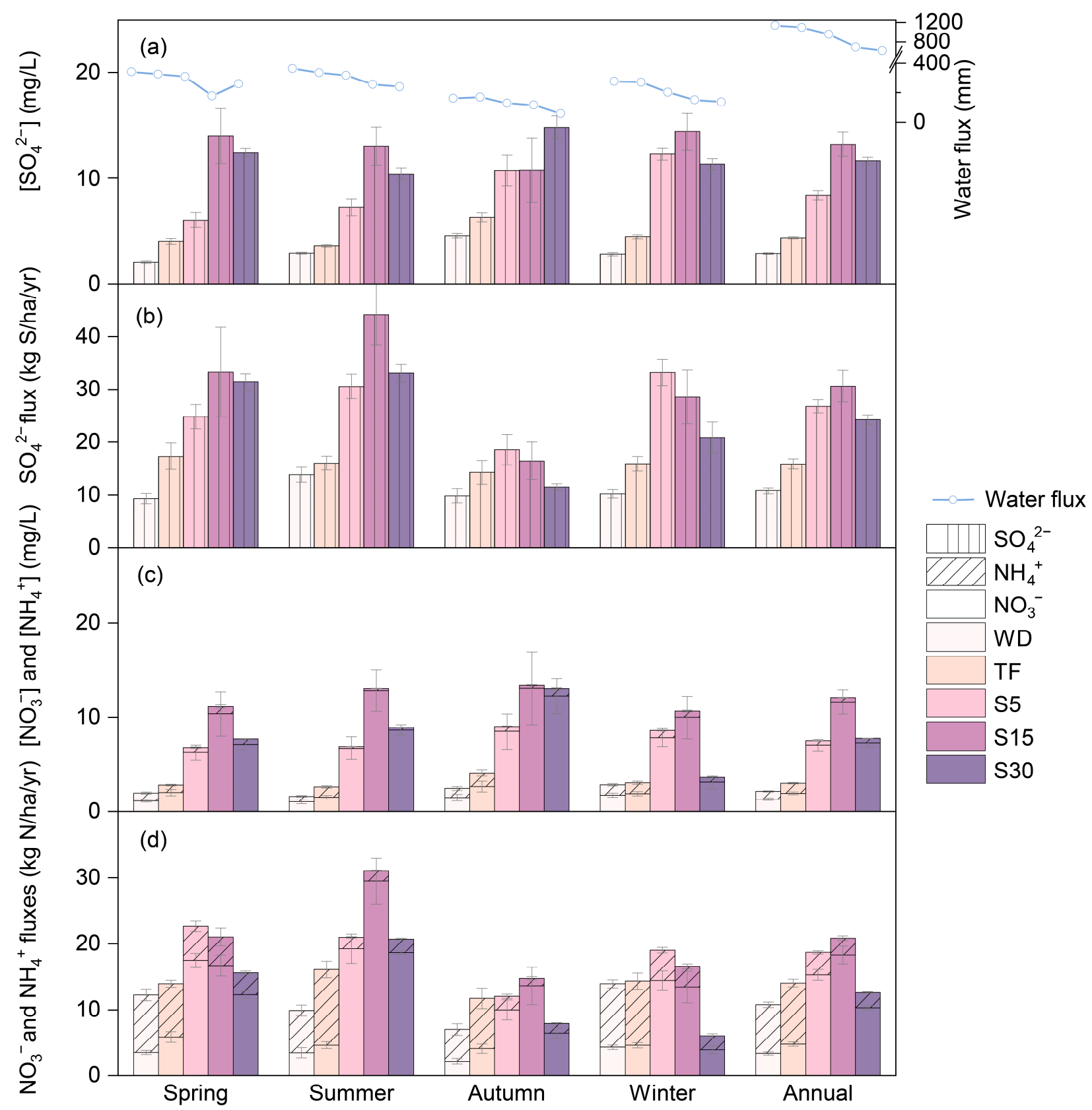

Figure 1. Seasonal water fluxes (a), $\mathrm{SO}_{4}{ }^{2-}$ concentrations (a), $\mathrm{SO}_{4}{ }^{2-}$ fluxes (b), DIN concentrations (c), and DIN fluxes (d) of wet deposition (WD), throughfall deposition (TF), and soil water in the top layer (S5, $5 \mathrm{~cm} \mathrm{depth),} 15 \mathrm{~cm}$ (S15), and below the root zone (S30, $30 \mathrm{~cm}$ depth) in 2018. Bars filled with vertical lines and bias are $\mathrm{SO}_{4}{ }^{2-}$ and $\mathrm{NH}_{4}{ }^{+}$, respectively, and bars without filling are $\mathrm{NO}_{3}{ }^{-}$. Error bars are standard errors.

\subsection{Decreasing Trend of Atmospheric DIN and S Depositions}

From 2014-2015 to 2017-2018, the annual mean concentrations of $\mathrm{SO}_{4}{ }^{2-}$ and DIN in precipitation decreased by $48 \%$ and $30 \%$, respectively. Meanwhile, the wet deposition of $\mathrm{SO}_{4}{ }^{2-}$ and DIN decreased by $63 \%$ and $55 \%$, respectively (Figure 2). The wet depositions of $\mathrm{SO}_{4}{ }^{2-}$ and DIN were relatively higher in 2018 than those in 2017, even with smaller anthropogenic emissions. This was possibly due to significantly less precipitation in 2017 (1467 mm, $978 \mathrm{~mm}$, and $1133 \mathrm{~mm}$ precipitation in 2014, 2017, and 2018, respectively). Compared with results in 2014 [25], with exactly the same sampling protocol and places, the throughfall deposition of $\mathrm{SO}_{4}{ }^{2-}, \mathrm{NO}_{3}{ }^{-}$, and $\mathrm{NH}_{4}{ }^{+}$in 2017-2018 decreased by $59 \%$, $69 \%$, and $31 \%$, respectively. In addition, during 2017-2018, total emissions of $\mathrm{SO}_{2}, \mathrm{NO}_{\mathrm{x}}$, 
and $\mathrm{NH}_{3}$ in Jiangxi Province decreased by 53\%, 11\%, and 17\%, respectively, from 2014-2015 (Figure 2). The declining trend of $S$ deposition was accordant with other field investigations across forests in China [4,8], following the rigorous air pollution control and adjustment of energy production structures in China [8-10]. In the case of $\mathrm{N}$, wet deposition of $\mathrm{NO}_{3}{ }^{-}$ responded quickly to the regional emission reduction, while wet deposition of $\mathrm{NH}_{4}{ }^{+}$remained relatively stable, fluctuating in a range of $6.25-7.38 \mathrm{~kg} \mathrm{~N} / \mathrm{ha} / \mathrm{yr}$, possibly due to nearby agricultural fields. Similar temporal patterns of $\mathrm{NO}_{3}{ }^{-}$and $\mathrm{NH}_{4}{ }^{+}$in precipitations at this site have also been observed at other background sites (forest, coastal, and grassland [38]) across China, where significantly decreased $\mathrm{NO}_{3}{ }^{-}$deposition and relatively stable $\mathrm{NH}_{4}{ }^{+}$deposition [10] were monitored from 2011 to 2018. Furthermore, $\mathrm{SO}_{2}, \mathrm{NO}_{\mathrm{x}}$, and $\mathrm{NH}_{3}$ emissions have been anticipated to continue decreasing across China [39], implying further declines of $\mathrm{S}$ and $\mathrm{N}$ deposition nationwide. Nevertheless, $\mathrm{NH}_{4}{ }^{+}$deposition via precipitations at this site could possibly remain stable due to uncontrolled $\mathrm{NH}_{3}$ emissions from nearby agricultural activities. Furthermore, S and N depositions in 2017-2018 in this forest were both at lower levels of corresponding depositions across forests in South China [10,31-33], but these were higher than those recently observed in most temperate and boreal forests across Europe-0.576-13.6 kg S/ha/yr and 1.27-19.2 kg N/ha/yr [1,3,40]and in North America-2.00-23.0 kg S/ha/yr and 1.15-11.0 kg N/ha/yr [15,18,20,41]. The relatively high levels of $\mathrm{S}$ and $\mathrm{N}$ deposition in this and other forests in South China emphasized the impacts of widespread anthropogenic emissions of $\mathrm{SO}_{2}$ and reactive nitrogen across subtropical zones [10].
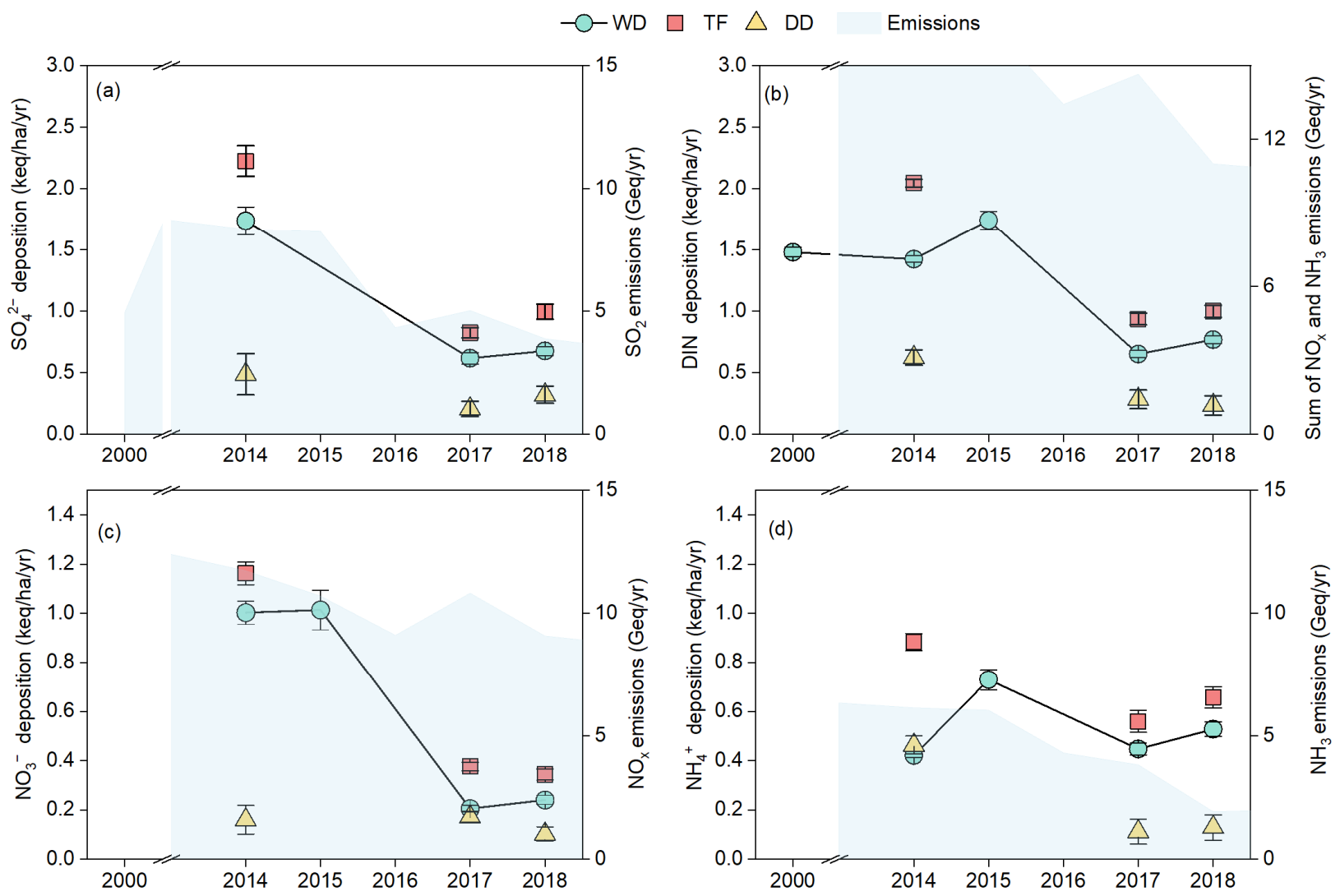

Figure 2. Yearly depositions of $\mathrm{SO}_{4}{ }^{2-}$ (a), $\mathrm{DIN}(\mathbf{b}), \mathrm{NO}_{3}{ }^{-}$(c), and $\mathrm{NH}_{4}{ }^{+}$(d) via wet deposition (WD), throughfall deposition (TF), and dry deposition (DD) to forests at Qianyanzhou station. Data in 2000, 2014, and 2015 are attained from Refs. [22,25,42], respectively, with the same sampling method. The error bars and shadowed area are standard errors and total emissions of related air pollutants in Jiangxi Province $[43,44]$, respectively.

Additionally, the regionally declined anthropogenic emissions seemed to have little influence on the dry deposition of $\mathrm{SO}_{2}\left(\right.$ or $\mathrm{H}_{2} \mathrm{SO}_{4}$ in the fog [21]) and $\mathrm{NO}_{\mathrm{x}}$ (or nitric acid 
and particulate nitrate [10]) at this site. Contrastively, dry deposition of $\mathrm{NH}_{3}$ (or particulate ammonium [10]) largely decreased. The regional distribution of industrial plants and various canopy interception (Section 3.1) of solutes could induce the different responses of dry deposition of $S$, oxidized $N$, and reduced $N$ to regional emission reductions. According to previous monitoring and estimation nationwide in China $[10,11]$, contributions of $N$ dry deposition are generally increasing since 2011. At this forested site, the importance of $S$ and $\mathrm{N}$ dry depositions increased in recent years, following decreases in corresponding wet depositions. Moreover, during 2014-2015, the oxidized N deposition overrode the reduced $\mathrm{N}$ deposition, which shifted to the contrary in 2017-2018. Agricultural activities nearby might become the main sources of $\mathrm{N}$ deposition at this site in the future.

\subsection{Net $N$ Retention and Excess $S$ Export in Soil under Declining Depositions}

Excess $\mathrm{N}$ export was observed in the upper soil (0-15 cm depth), while net $\mathrm{N}$ retention was observed in the deeper soil $(15-30 \mathrm{~cm})$. The $\mathrm{N}$ leaching from the root zone accounted for $75 \%$ of the total deposition (Figure 2 and Table 1 ). According to previous investigations in South China, $\mathrm{N}$ saturation threshold in acidic subtropical forest soils was estimated as $26 \mathrm{~kg} \mathrm{~N} / \mathrm{ha} / \mathrm{yr}$ [33]. In 2014-2015, total DIN deposition at this site was larger than $28 \mathrm{~kg} \mathrm{~N} / \mathrm{ha} / \mathrm{yr}$, and the leaching constituted $23 \%$ of throughfall deposition $\sim 40 \mathrm{~cm}$ below soil [22]. Even though the DIN deposition at this site in 2017-2018 was smaller than the saturation threshold [33], significant DIN leaching still occurred and accounted for a larger proportion of the throughfall input than that during 2014-2015. A higher ratio of N leaching to $\mathrm{N}$ deposition has also been monitored in a subtropical forest in Southwest China [13] and some temperate forests $[14,45]$ under declined deposition. Considering the enhanced N leaching under declined deposition, this site was likely undergoing a "transition" state and required longer time to approach a "new" steady sate [2].

Table 1. Retention and excess $\mathrm{S}$ and $\mathrm{N}$ output ${ }^{1}$ and $\mathrm{H}^{+}$production along the soil profile in 2018.

\begin{tabular}{|c|c|c|c|c|c|}
\hline Season & Layer of Soil ${ }^{2}$ & Soil Water Flux (mm) & Excess S Output (kg S/ha) & Excess N Output (kg N/ha) & $\mathrm{H}^{+}{ }_{\text {prod, } \mathrm{N}}(\mathrm{kmol} / \mathrm{ha})$ \\
\hline \multirow{4}{*}{ Spring } & $0-5 \mathrm{~cm}$ & 308 & $1.87 \pm 0.85$ & $2.19 \pm 0.41$ & $3.60 \pm 0.41$ \\
\hline & $5-15 \mathrm{~cm}$ & 178 & $2.12 \pm 2.36$ & $-0.40 \pm 0.71$ & $0.02 \pm 0.71$ \\
\hline & $15-30 \mathrm{~cm}$ & 190 & $-0.46 \pm 2.22$ & $-1.37 \pm 0.65$ & $-0.86 \pm 0.65$ \\
\hline & $0-5 \mathrm{~cm}$ & 316 & $3.62 \pm 0.67$ & $1.23 \pm 0.66$ & $6.08 \pm 0.66$ \\
\hline \multirow[t]{3}{*}{ Summer } & $5-15 \mathrm{~cm}$ & 255 & $3.40 \pm 1.65$ & $2.52 \pm 1.15$ & $2.58 \pm 1.15$ \\
\hline & $15-30 \mathrm{~cm}$ & 240 & $-2.77 \pm 1.51$ & $-2.59 \pm 1.00$ & $-2.83 \pm 1.00$ \\
\hline & $0-5 \mathrm{~cm}$ & 130 & $1.06 \pm 0.91$ & $0.08 \pm 0.56$ & $2.87 \pm 0.56$ \\
\hline \multirow[t]{3}{*}{ Autumn } & $5-15 \mathrm{~cm}$ & 115 & $-0.52 \pm 1.38$ & $0.68 \pm 1.00$ & $1.12 \pm 1.00$ \\
\hline & $15-30 \mathrm{~cm}$ & 58 & $-1.23 \pm 1.07$ & $-1.7 \pm 0.94$ & $-1.85 \pm 0.94$ \\
\hline & $0-5 \mathrm{~cm}$ & 202 & $4.32 \pm 0.71$ & $1.18 \pm 0.49$ & $3.71 \pm 0.49$ \\
\hline \multirow[t]{3}{*}{ Winter } & $5-15 \mathrm{~cm}$ & 149 & $-1.16 \pm 1.5$ & $-0.62 \pm 0.85$ & $0.12 \pm 0.85$ \\
\hline & $15-30 \mathrm{~cm}$ & 138 & $-1.93 \pm 1.34$ & $-2.63 \pm 0.78$ & $-2.11 \pm 0.78$ \\
\hline & $0-5 \mathrm{~cm}$ & 957 & $10.87 \pm 1.58$ & $4.68 \pm 1.08$ & $16.26 \pm 1.08$ \\
\hline \multirow[t]{2}{*}{ Annual } & $5-15 \mathrm{~cm}$ & 697 & $3.83 \pm 3.53$ & $2.18 \pm 1.88$ & $3.85 \pm 1.88$ \\
\hline & $15-30 \mathrm{~cm}$ & 626 & $-6.37 \pm 3.18$ & $-8.29 \pm 1.71$ & $-7.65 \pm 1.71$ \\
\hline
\end{tabular}

${ }^{1}$ Calculated as difference between leaching flux in the layer and the upper layer or the throughfall input for topsoil (0-5 cm). For N, both $\mathrm{NO}_{3}{ }^{-}$and $\mathrm{NH}_{4}{ }^{+}$were included. Positive values indicated excess export, otherwise nutrient retention or gaseous loss in the soil. ${ }^{2}$ Excess export at S5, S15, and S30 were considered as from the topsoil, root zone, and deeper soil (below the root zone), respectively.

The net $\mathrm{N}$ retention and leaching are affected by many factors, as $\mathrm{NO}_{3}{ }^{-}$and $\mathrm{NH}_{4}{ }^{+}$ could experience complexed transformation processes apart from deposition and leaching in soil [46-48]. Since roots of Pinus massoniana prefer $\mathrm{NO}_{3}{ }^{-}$rather than $\mathrm{NH}_{4}{ }^{+}[13,33], \mathrm{NH}_{4}{ }^{+}$ immobilization by microbes and autotrophic nitrification are considered as major pathways of $\mathrm{NH}_{4}{ }^{+}$consumption. Meanwhile, $\mathrm{NH}_{4}{ }^{+}$in soil could be produced from mineralization and dissimilatory reduction of nitrate to ammonium (DNRA) $[13,48]$. According to the ${ }^{15} \mathrm{~N}$ tracing experiment of forest soil in this region, the potential of autotrophic nitrification and DNRA was low, possibly due to the low soil $\mathrm{pH}$ [48], which has also been observed in other subtropical forests $[13,49,50]$. Hence, the largely declined $\mathrm{NH}_{4}{ }^{+}$fluxes in soil water were more likely due to the predominance of $\mathrm{NH}_{4}{ }^{+}$immobilization, which then accumulated in the organic matters. In the case of $\mathrm{NO}_{3}{ }^{-}$, nitrification (including autotrophic nitrification 
and heterotrophic nitrification) is considered as another important source of $\mathrm{NO}_{3}{ }^{-}$in soil, aside from atmospheric deposition. Meanwhile, vegetation uptake, immobilization, denitrification, and DNRA are major pathways for $\mathrm{NO}_{3}{ }^{-}$consumption [48]. As described above, the distinctly increased $\mathrm{NO}_{3}{ }^{-}$fluxes in soil water from throughfall deposition implied the dominance of heterotrophic nitrification and mineralization processes over the $\mathrm{NO}_{3}{ }^{-}$ consumption. Additionally, mineralization of litterfall could also increase $\mathrm{NO}_{3}{ }^{-}$leaching in the organic layer, suggested by the rapid internal $\mathrm{N}$ cycle in subtropical forests [8]. Moreover, heterotrophic nitrification and $\mathrm{N}$ mineralization rate in subtropical forest soils possibly had a delayed recovery to the declined deposition [13], which eventually led to the increased ratio of $\mathrm{N}$ leaching to $\mathrm{N}$ deposition. In addition, $\mathrm{NO}_{3}{ }^{-}$flux at $\mathrm{S} 30$ significantly declined, compared with that at $S 15$. Since the roots were concentrated at $0-20 \mathrm{~cm}$ depth [30], the vegetation uptake was unlikely to have induced the declined leaching. In contrast, denitrification process in soil could possibly take an important role in $\mathrm{N}$ mass balance [22]. The increasing humidity of soil and relatively stable soil temperature until $50 \mathrm{~cm}$ depth at this site [51] all benefitted the denitrification process in deeper soil.

In the case of $\mathrm{SO}_{4}{ }^{2-}$, excess $\mathrm{S}$ tended to be exported from soil (Table 1), which has been widely reported across forests in Europe [1,2] and North America [18,20] during the recovery from historically high $S$ deposition. Mineralization of organic S, desorption of previous adsorbed $\mathrm{SO}_{4}{ }^{2-}$ and bedrock weathering could all possibly contribute to the significant $S$ export $[1,2,18,20,52,53]$. As the red earth at this site is highly weathered [17,54], weathering in the surface soil could be minor. Concomitant with high $\mathrm{S}$ deposition across South China $[6,8,32]$, plenty $\mathrm{S}$ was stored in soil in forms of adsorbed $\mathrm{SO}_{4}{ }^{2-}$, organic $\mathrm{S}$, and/or reduced S [55], ranging 10.4-50.0 kg S/ha/yr [21,56]. The adsorption-desorption of $\mathrm{SO}_{4}{ }^{2-}$ follows the Freundlich equation, and absorbed $\mathrm{SO}_{4}{ }^{2-}$ on soil minerals could be released to soil solution again [57] under conditions of decreasing $\mathrm{SO}_{4}{ }^{2-}$ concentrations in soil solution and increasing soil pH. Additionally, in the topsoil and humous layer, the organic $\mathrm{S}$ predominated among adsorbed $\mathrm{SO}_{4}{ }^{2-}$ and other $\mathrm{S}$ species $[54,56,58-60]$, and might participate in secondary production of $\mathrm{SO}_{4}{ }^{2-}[58,61,62]$. The excess $\mathrm{SO}_{4}{ }^{2-}$ export in this forest possibly resulted from legacy effects of historic $\mathrm{S}$ deposition, e.g., desorption of previously adsorbed $\mathrm{SO}_{4}{ }^{2-}$ [8] and mineralization of accumulated organic $\mathrm{S}[52,58]$. In a subtropical forest in Southwest China, the $\mathrm{SO}_{4}{ }^{2-}$ leaching decreased concomitantly with the $\mathrm{SO}_{4}{ }^{2-}$ deposition (180 kg S/ha/yr) but $\mathrm{S}$ remained to be accumulated in soil [8]. Contrastively, this site received much smaller $\mathrm{S}$ deposition, and excess $\mathrm{SO}_{4}{ }^{2-}$ was exported from the soil. The different status of $S$ export between the two subtropical sites might result from different capacity of $\mathrm{SO}_{4}{ }^{2-}$ adsorption in soils [63] and $\mathrm{SO}_{4}{ }^{2-}$ concentrations in the throughfall [57]. Along the soil profile, excess export of $S$ mainly appeared at $S 5$ and S15, while significant retention process occurred at S30 (Table 1). The immobilization of $\mathrm{SO}_{4}{ }^{2-}$ by microbes, $\mathrm{SO}_{4}{ }^{2-}$ re-adsorption, and $\mathrm{SO}_{4}{ }^{2-}$ reduction could induce $\mathrm{S}$ retention or removal $[52,53,64]$ in the deeper soil. Determination of relative importance of these biogeochemistry processes requires further investigation. Moreover, regarding the declining trend of $\mathrm{S}$ emissions and deposition across South China [9,32], inherent sources of $\mathrm{SO}_{4}{ }^{2-}$ from soils might become more and more important for subtropical forests [3,18].

Notably, the excess exports of $\mathrm{N}$ and $\mathrm{S}$ were larger in the spring and summer, when the water fluxes were abundant. The positive correlation between excess export of $\mathrm{S}$ (or $\mathrm{N}$ ) and the water flux (Table $1, p<0.05$ ) was commonly observed in various forests $[1,2,17,18]$ and meadow ecosystems [3]. Increased rainfall intensity could enhance the mineralization process together with $\mathrm{SO}_{4}{ }^{2-}$ desorption $[3,18]$, leading to increased $\mathrm{N}$ and $\mathrm{S}$ leaching. During the recovery from acidification in a forested catchment in Japan, the forest soil was prone to retain $\mathrm{SO}_{4}{ }^{2-}$ under elevated air temperature and rainfall intensity due to prolonged growth season [3]. In this study, vegetation uptake and immobilization seemed to play a minor role in controlling $\mathrm{SO}_{4}{ }^{2-}$ budget in surface soil, but the climate conditions, e.g., rainfall intensity, tended to predominate in regulating $\mathrm{SO}_{4}{ }^{2-}$ leaching and retention. Additionally, the excess $S$ leaching due to previously adsorbed $S$ and/or accumulated organic $S$ from soil is often accompanied with enhanced leaching of $\mathrm{Al}^{3+}$ and base cations, which delays 
the recovery of forest soil and surface water from acidification [18]. Furthermore, during the transformation between $\mathrm{NH}_{4}{ }^{+}$and $\mathrm{NO}_{3}{ }^{-}$, protons could be generated, preventing the increase in soil water $\mathrm{pH}$ [17]. Significant acidification occurred at the topsoil and root zones (when intensive precipitations appeared), with $38 \%$ of generated $\mathrm{H}^{+}$being neutralized below the root zone (Table 1). Predictably, the significant leaching of DIN and $\mathrm{SO}_{4}{ }^{2-}$ could possibly continue for a long time in subtropical forests even under decreasing depositions in the future, resulting in persistent risks in acidification and eutrophication of terrestrial and aquatic ecosystems.

\section{Conclusions}

In this study, the wet and throughfall deposition and the solute fluxes along the soil profile were consecutively monitored in a mildly polluted subtropical forest in Southeast China in 2017-2018. From 2014-2015 to 2017-2018, the total deposition of $\mathrm{SO}_{4}{ }^{2-}, \mathrm{NO}_{3}{ }^{-}$, and $\mathrm{NH}_{4}{ }^{+}$decreased by $59 \%, 69 \%$, and $31 \%$, respectively, while the dry deposition of $\mathrm{S}$ and oxidized $\mathrm{N}$ remained relatively stable at this site. In addition, the $\mathrm{NH}_{4}{ }^{+}$deposition was shifted to dominate DIN deposition in 2017-2018. Deposition of $\mathrm{S}$ and $\mathrm{NO}_{3}{ }^{-}$could possibly continue decreasing while $\mathrm{NH}_{4}{ }^{+}$deposition tended to remain stable at this site. Even though DIN deposition at this site decreased below the $\mathrm{N}$ saturation threshold, approximately $75 \%$ of deposited DIN still leached from the root zone. The significant leaching of DIN under declined atmospheric deposition possibly resulted from the delayed responses of mineralization and nitrification rates in subtropical forest soils to declined $\mathrm{N}$ deposition. Net S export from soil was observed at this site, amounting to $8.32 \pm 0.48 \mathrm{~kg} \mathrm{~S} / \mathrm{ha} / \mathrm{yr}$, which might result from the legacy effects of historically high $\mathrm{S}$ deposition. This site was likely undergoing a "transition" state and required longer time to approach a "new" steady sate. The continuous leaching of $\mathrm{N}$ and $\mathrm{S}$ could possibly delay the recovery of soil and surface water from acidification. Furthermore, the rainfall intensity remarkably regulated leaching and retention of $\mathrm{SO}_{4}{ }^{2-}$ and DIN at this site. The climate changes, e.g., higher temperature and more intensified rainfalls, could influence the $\mathrm{S}$ and $\mathrm{N}$ cycles in forest ecosystems. Hence, even though declined $\mathrm{N}$ and $\mathrm{S}$ depositions have been anticipated across China, the impacts of climate change, excess $\mathrm{S}$ export, and continuous DIN leaching to the forest ecosystem health and acidification recovery require further long-term monitoring in subtropical forests.

Author Contributions: Conceptualization, P.K. and Q.Y.; investigation, P.K., G.S., Y.L. and Z.C.; visualization, P.K. and Q.Y.; writing—original draft preparation, P.K.; methodology, G.S., Y.L. and Z.C.; writing—review and editing, Q.Y. and L.D.; funding acquisition, Q.Y. and L.D.; supervision, L.D.; project administration, L.D. All authors have read and agreed to the published version of the manuscript.

Funding: This research was funded by the National Natural Science Foundation of China, grant number 41877329 and 21607019, the special fund of State Key Joint Laboratory of Environment Simulation and Pollution Control, grant number 19L02ESPC, and China Postdoctoral Science Foundation, grant number 2020M670353.

Data Availability Statement: Data is contained within the article.

Acknowledgments: The authors greatly acknowledge the support from Qianyanzhou Forest Experimental Station and the help received in system maintenance and laboratory measurement from Yuanfen Huang and Jiawei Zhang and language editing from Loreena K. Avery and Harold W. Avery.

Conflicts of Interest: The authors declare no conflict of interest. 


\section{Appendix A}

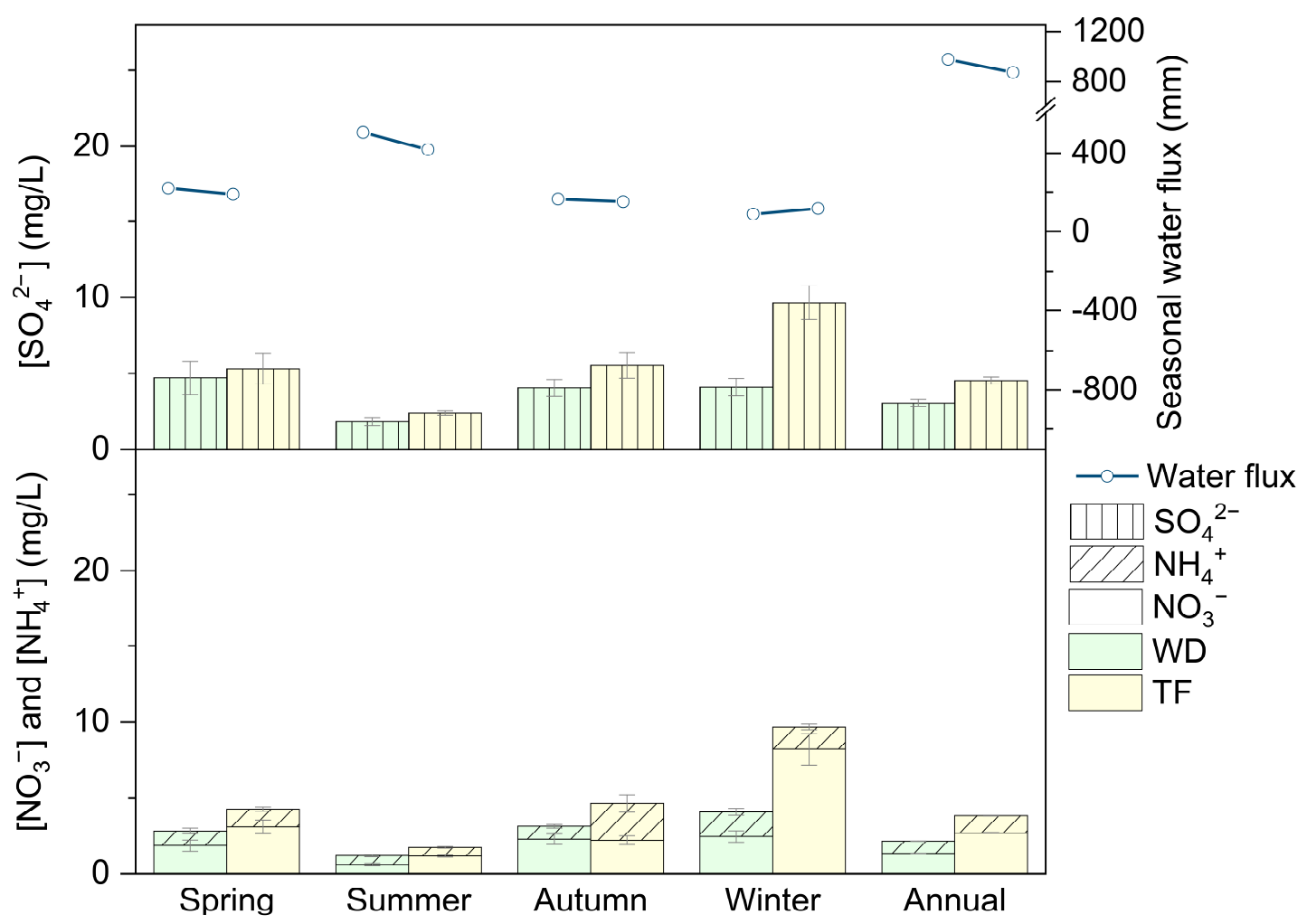

Figure A1. Seasonal water flux and ion concentrations of wet deposition (WD) and throughfall deposition (TF) in 2017. Bars filled with vertical lines, bars filled with bias, and bars without filling indicate $\mathrm{SO}_{4}{ }^{2-}, \mathrm{NH}_{4}{ }^{+}$, and $\mathrm{NO}_{3}{ }^{-}$, respectively.

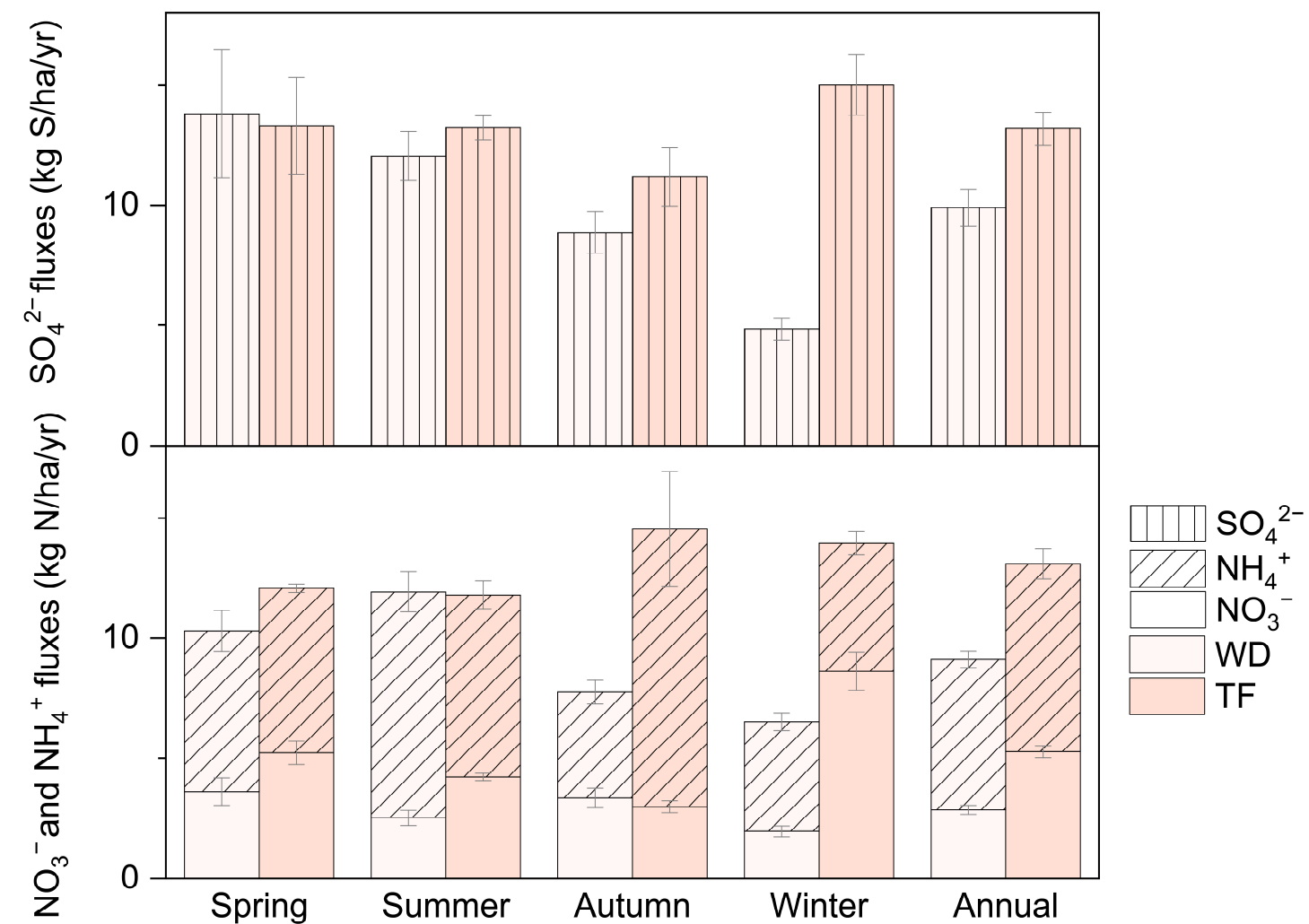

Figure A2. Seasonal flux of wet deposition (WD) and throughfall deposition (TF) in 2017. Bars filled with vertical lines, bars filled with bias, and bars without filling indicate $\mathrm{SO}_{4}{ }^{2-}, \mathrm{NH}_{4}{ }^{+}$, and $\mathrm{NO}_{3}{ }^{-}$, respectively. 


\section{References}

1. Vuorenmaa, J.; Augustaitis, A.; Beudert, B.; Bochenek, W.; Clarke, N.; de Wit, H.A.; Dirnboeck, T.; Frey, J.; Hakola, H.; Kleemola, S.; et al. Long-term changes (1990-2015) in the atmospheric deposition and runoff water chemistry of sulphate, inorganic nitrogen and acidity for forested catchments in Europe in relation to changes in emissions and hydrometeorological conditions. Sci. Total Environ. 2018, 625, 1129-1145. [CrossRef]

2. Vuorenmaa, J.; Augustaitis, A.; Beudert, B.; Clarke, N.; Wit, H.A.d.; Dirnböck, T.; Frey, J.; Forsius, M.; Indriksone, I.; Kleemola, S.; et al. Long-term sulphate and inorganic nitrogen mass balance budgets in European ICP Integrated Monitoring catchments (1990-2012). Ecol. Indic. 2017, 76, 15-29. [CrossRef]

3. Kopacek, J.; Kana, J.; Porcal, P.; Stuchlik, E. Diverse effects of accelerating climate change on chemical recovery of alpine lakes from acidic deposition in soil-rich versus scree-rich catchments. Environ. Pollut. 2021, 284, 117522. [CrossRef]

4. Duan, L.; Yu, Q.; Zhang, Q.; Wang, Z.; Pan, Y.P.; Larssen, T.; Tang, J.; Mulder, J. Acid deposition in Asia: Emissions, deposition, and ecosystem effects. Atmos. Environ. 2016, 146, 55-69. [CrossRef]

5. Aber, J.; McDowell, W.; Nadelhoffer, K.; Magill, A.; Berntson, G.; Kamakea, M.; McNulty, S.; Currie, W.; Rustad, L.; Fernandez, I. Nitrogen saturation in temperate forest ecosystems-Hypotheses revisited. Bioscience 1998, 48, 921-934. [CrossRef]

6. Zhao, W.; Zhao, Y.; Ma, M.; Chang, M.; Duan, L. Long-term variability in base cation, sulfur and nitrogen deposition and critical load exceedance of terrestrial ecosystems in China. Environ. Pollut. 2021, 289, 117974. [CrossRef]

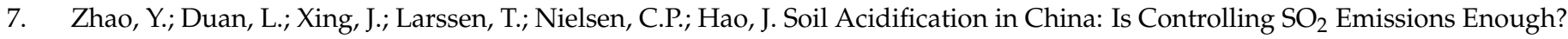
Environ. Sci. Technol. 2009, 43, 8021-8026. [CrossRef] [PubMed]

8. Yu, Q.; Zhang, T.; Ma, X.; Kang, R.; Mulder, J.; Larssen, T.; Duan, L. Monitoring Effect of SO2 Emission Abatement on Recovery of Acidified Soil and Streamwater in Southwest China. Environ. Sci. Technol. 2017, 51, 9498-9506. [CrossRef] [PubMed]

9. Zheng, B.; Tong, D.; Li, M.; Liu, F.; Hong, C.P.; Geng, G.N.; Li, H.Y.; Li, X.; Peng, L.Q.; Qi, J.; et al. Trends in China's anthropogenic emissions since 2010 as the consequence of clean air actions. Atmos. Chem. Phys. 2018, 18, 14095-14111. [CrossRef]

10. Wen, Z.; Xu, W.; Li, Q.; Han, M.; Tang, A.; Zhang, Y.; Luo, X.; Shen, J.; Wang, W.; Li, K.; et al. Changes of nitrogen deposition in China from 1980 to 2018. Environ. Int. 2020, 144, 106022. [CrossRef]

11. Yu, G.R.; Jia, Y.L.; He, N.P.; Zhu, J.X.; Chen, Z.; Wang, Q.F.; Piao, S.L.; Liu, X.J.; He, H.L.; Guo, X.B.; et al. Stabilization of atmospheric nitrogen deposition in China over the past decade. Nat. Geosci. 2019, 12, 424-429. [CrossRef]

12. Lu, X.; Vitousek, P.M.; Mao, Q.; Gilliam, F.S.; Luo, Y.; Zhou, G.; Zou, X.; Bai, E.; Scanlon, T.M.; Hou, E.; et al. Plant acclimation to long-term high nitrogen deposition in an N-rich tropical forest. Proc. Natl. Acad. Sci. USA 2018, 115, 5187-5192. [CrossRef] [PubMed]

13. Xie, D.; Duan, L.; Si, G.; Liu, W.; Zhang, T.; Mulder, J. Long-Term N-15 Balance After Single-Dose Input of N-15-Labeled NH4+ and NO3- in a Subtropical Forest Under Reducing N Deposition. Glob. Biogeochem. Cycle 2021, 35, e2021GB006959. [CrossRef]

14. Koopmans, C.J.; Lubrecht, W.C.; Tietema, A. Nitrogen transformations in two nitrogen saturated forest ecosystems subjected to an experimental decrease in nitrogen deposition. Plant Soil 1995, 175, 205-218. [CrossRef]

15. Gilliam, F.S.; Burns, D.A.; Driscoll, C.T.; Frey, S.D.; Lovett, G.M.; Watmough, S.A. Decreased atmospheric nitrogen deposition in eastern North America: Predicted responses of forest ecosystems. Environ. Pollut. 2019, 244, 560-574. [CrossRef] [PubMed]

16. Xie, D.N.; Zhang, T.; Yu, Q.; Huang, Y.M.; Mulder, J.; Duan, L. A Sharp Decline in Nitrogen Input in a N-Saturated Subtropical Forest Causes an Instantaneous Reduction in Nitrogen Leaching. J. Geophys. Res. Biogeosci. 2018, 123, 3320-3330. [CrossRef]

17. Huang, Y.; Kang, R.; Mulder, J.; Zhang, T.; Duan, L. Nitrogen saturation, soil acidification, and ecological effects in a subtropical pine forest on acid soil in southwest China. J. Geophys. Res.-Biogeosci. 2015, 120, 2457-2472. [CrossRef]

18. Mitchell, M.J.; Driscoll, C.T.; McHale, P.J.; Roy, K.M.; Dong, Z. Lake/watershed sulfur budgets and their response to decreases in atmospheric sulfur deposition: Watershed and climate controls. Hydrol. Process. 2013, 27, 710-720. [CrossRef]

19. Prechtel, A.; Alewell, C.; Armbruster, M.; Bittersohl, J.; Cullen, J.M.; Evans, C.D.; Helliwell, R.; Kopácek, J.; Marchetto, A.; Matzner, E.; et al. Response of sulphur dynamics in European catchments to decreasing sulphate deposition. Hydrol. Earth Syst. Sci. 2001, 5, 311-326. [CrossRef]

20. Marty, C.; Duchesne, L.; Couture, S.; Gagnon, C.; Houle, D. Effects of climate and atmospheric deposition on a boreal lake chemistry: A synthesis of 36 years of monitoring data. Sci. Total Environ. 2021, 758, 143639. [CrossRef]

21. Larssen, T.; Duan, L.; Mulder, J. Deposition and Leaching of Sulfur, Nitrogen and Calcium in Four Forested Catchments in China: Implications for Acidification. Environ. Sci. Technol. 2011, 45, 1192-1198. [CrossRef] [PubMed]

22. Gao, Y.; Hao, Z.; Han, N.; Yang, J.; Tian, J.; Song, X.; Wen, X.; He, N. Tracking the fate of deposited nitrogen and its redistribution in a subtropical watershed in China. Ecohydrology 2019, 12, e2094. [CrossRef]

23. Wen, X.F.; Wang, H.M.; Wang, J.L.; Yu, G.R.; Sun, X.M. Ecosystem carbon exchanges of a subtropical evergreen coniferous plantation subjected to seasonal drought, 2003-2007. Biogeosciences 2010, 7, 357-369. [CrossRef]

24. Xu, S.G.; Liu, Y.F.; Cui, Y.G.; Pei, Z.Y. Litter decomposition in a subtropical plantation in Qianyanzhou, China. J. Forest Res. 2011, 16, 8-15. [CrossRef]

25. Cheng, Z.; Luo, Y.; Zhang, T.; Duan, L. Deposition of sulfur, nitrogen and mercury in two typical forest ecosystems in southern China. Huanjing Kexue 2017, 38, 5004-5011. [CrossRef]

26. Ke, P.; Yu, Q.; Luo, Y.; Kang, R.; Duan, L. Fluxes of nitrogen oxides above a subtropical forest canopy in China. Sci. Total Environ. 2020, 715, 136993. [CrossRef] 
27. Yu, Q.; Luo, Y.; Wang, S.x.; Wang, Z.q.; Hao, J.M.; Duan, L. Gaseous elemental mercury (GEM) fluxes over canopy of two typical subtropical forests in south China. Atmos. Chem. Phys. 2018, 18, 495-509. [CrossRef]

28. Wang, Y.; Wang, H.; Xu, M.; Ma, Z.; Wang, Z.-L. Soil organic carbon stocks and CO2 effluxes of native and exotic pine plantations in subtropical China. Catena 2015, 128, 167-173. [CrossRef]

29. Fu, X.; Wang, J.; Wang, H.; Dai, X.; Yang, F.; Zhao, M. Response of the fine root production, phenology, and turnover rate of six shrub species from a subtropical forest to a soil moisture gradient and shading. Plant Soil 2016, 399, 135-146. [CrossRef]

30. Mo, X.; Dai, X.; Wang, H.; Fu, X.; Kou, L. Rhizosphere effects of overstory tree and understory shrub species in central subtropical plantations-A case study at Qianyanzhou, Taihe, Jiangxi, China. Chin. J. Plant Ecol. 2018, 42, 723-733. [CrossRef]

31. Du, E. A database of annual atmospheric acid and nutrient deposition to China's forests. Sci. Data 2018, 5, 180223. [CrossRef]

32. Yu, Q.; Duan, L.; Hao, J. Acid deposition in China: Sources, effects and control. Acta Sci. Circumstantiae 2021, 41, 731-746.

33. Yu, Q.; Duan, L.; Yu, L.; Chen, X.; Si, G.; Ke, P.; Ye, Z.; Mulder, J. Threshold and multiple indicators for nitrogen saturation in subtropical forests. Environ. Pollut. 2018, 241, 664-673. [CrossRef]

34. Lin, Y. Water cycling model for ganjiang watershed. Resour. Sci. 1998, 20, 17-23.

35. Fenn, M.E.; Ross, C.S.; Schilling, S.L.; Baccus, W.D.; Larrabee, M.A.; Lofgren, R.A. Atmospheric deposition of nitrogen and sulfur and preferential canopy consumption of nitrate in forests of the Pacific Northwest, USA. Forest Ecol. Manag. 2013, 302, 240-253. [CrossRef]

36. Hao, Z.; Gao, Y.; Zhang, J.-z.; Yu, G.-r. Chemical Characteristics of Atmospheric Wet Deposition in Winter and Its Forestry Canopy Interception Mechanism in Red Soil Hilly Area. Huanjing Kexue 2015, 36, 4403-4413.

37. Vanbreemen, N.; Driscoll, C.T.; Mulder, J. Acidic deposition and internal proton sources in acidification of soils and waters. Nature 1984, 307, 599-604. [CrossRef]

38. Xu, W.; Luo, X.S.; Pan, Y.P.; Zhang, L.; Tang, A.H.; Shen, J.L.; Zhang, Y.; Li, K.H.; Wu, Q.H.; Yang, D.W.; et al. Quantifying atmospheric nitrogen deposition through a nationwide monitoring network across China. Atmos. Chem. Phys. 2015, 15, 12345-12360. [CrossRef]

39. Xing, J.; Lu, X.; Wang, S.; Wang, T.; Ding, D.; Yu, S.; Shindell, D.; Ou, Y.; Morawska, L.; Li, S.; et al. The quest for improved air quality may push China to continue its CO2 reduction beyond the Paris Commitment. Proc. Natl. Acad. Sci. USA 2020, 117, 29535-29542. [CrossRef]

40. Forsius, M.; Posch, M.; Holmberg, M.; Vuorenmaa, J.; Kleemola, S.; Augustaitis, A.; Beudert, B.; Bochenek, W.; Clarke, N.; de Wit, H.A.; et al. Assessing critical load exceedances and ecosystem impacts of anthropogenic nitrogen and sulphur deposition at unmanaged forested catchments in Europe. Sci. Total Environ. 2021, 753, 141791. [CrossRef]

41. Lawrence, G.B.; Scanga, S.E.; Sabo, R.D. Recovery of Soils from Acidic Deposition May Exacerbate Nitrogen Export from Forested Watersheds. J. Geophys. Res.-Biogeosci. 2020, 125, e2019JG005036. [CrossRef]

42. Chen, Y.; Liu, Y.; Lin, Y.; Li, J.; Zhang, H. Hydrological process and nutrient dynamics of schima superba stand in qianyanzhou experimental areas, jiangxi province. Sci. Silvae Sin. 2003, 39, 145-150.

43. National Bureau of Statistics of China. Available online: http:/ / data.stats.gov.cn/ (accessed on 16 August 2021).

44. Ministry of Ecology and Environment of the People's Republic of China. Available online: http://www.mee.gov.cn/ (accessed on 16 August 2021).

45. Corre, M.D.; Lamersdorf, N.P. Reversal of nitrogen saturation after long-term deposition reduction: Impact on soil nitrogen cycling. Ecology 2004, 85, 3090-3104. [CrossRef]

46. Niu, S.; Classen, A.T.; Dukes, J.S.; Kardol, P.; Liu, L.; Luo, Y.; Rustad, L.; Sun, J.; Tang, J.; Templer, P.H.; et al. Global patterns and substrate-based mechanisms of the terrestrial nitrogen cycle. Ecol. Lett. 2016, 19, 697-709. [CrossRef]

47. Galloway, J.N.; Dentener, F.J.; Capone, D.G.; Boyer, E.W.; Howarth, R.W.; Seitzinger, S.P.; Asner, G.P.; Cleveland, C.C.; Green, P.A.; Holland, E.A.; et al. Nitrogen Cycles: Past, Present, and Future. Biogeochemistry 2004, 70, 153-226. [CrossRef]

48. Gao, W.; Kou, L.; Yang, H.; Zhang, J.; Mueller, C.; Li, S. Are nitrate production and retention processes in subtropical acidic forest soils responsive to ammonium deposition? Soil Biol. Biochem. 2016, 100, 102-109. [CrossRef]

49. Liu, W.; Yu, L.; Zhang, T.; Kang, R.; Zhu, J.; Mulder, J.; Huang, Y.; Duan, L. In situ 15N labeling experiment reveals different long-term responses to ammonium and nitrate inputs in N-saturated subtropical forest. J. Geophys. Res. Biogeosci. 2017, 122, 2251-2264. [CrossRef]

50. Zhang, Y.C.; Zhang, J.B.; Meng, T.Z.; Zhu, T.B.; Muller, C.; Cai, Z.C. Heterotrophic nitrification is the predominant $\mathrm{NO}_{3}{ }^{-}$ production pathway in acid coniferous forest soil in subtropical China. Biol. Fertil. Soils 2013, 49, 955-957. [CrossRef]

51. Zhang, L.; Luo, Y.; Liu, M.; Chen, Z.; Su, W.; He, H.; Zhu, Z.; Sun, X.; Wang, Y.; Zhou, G.; et al. Carbon and water fluxes observed by the Chinese Flux Observation and Research Network (2003-2005). China Sci. Data 2019, 4, 18-34.

52. Sase, H.; Saito, T.; Takahashi, M.; Morohashi, M.; Yamashita, N.; Inomata, Y.; Ohizumi, T.; Nakata, M. Transboundary air pollution reduction rapidly reflected in stream water chemistry in forested catchment on the sea of Japan coast in central Japan. Atmos. Environ. 2021, 248, 118223. [CrossRef]

53. Sase, H.; Takahashi, M.; Matsuda, K.; Sato, K.; Tanikawa, T.; Yamashita, N.; Ohizumi, T.; Ishida, T.; Kamisako, M.; Kobayashi, R.; et al. Response of river water chemistry to changing atmospheric environment and sulfur dynamics in a forested catchment in central Japan. Biogeochemistry 2019, 142, 357-374. [CrossRef]

54. Wang, Z.; Zhang, X.; Zhang, Y.; Wang, Z.; Mulder, J. Accumulation of different sulfur fractions in Chinese forest soil under acid deposition. J. Environ. Monit. 2011, 13, 2463-2470. [CrossRef] 
55. Johnson, D.W. Sulfur cycling in forests. Biogeochemistry 1984, 1, 29-43. [CrossRef]

56. Zhang, W.; Liu, C.-Q.; Wang, Z.-L.; Zhang, L.-L.; Luo, X.-Q. Speciation and Isotopic Composition of Sulfur in Limestone Soil and Yellow Soil in Karst Areas of Southwest China: Implications of Different Responses to Acid Deposition. J. Environ. Qual. 2014, 43, 809-819. [CrossRef]

57. Gustafsson, J.P.; Akram, M.; Tiberg, C. Predicting sulphate adsorption/desorption in forest soils: Evaluation of an extended Freundlich equation. Chemosphere 2015, 119, 83-89. [CrossRef] [PubMed]

58. Houle, D.; Carignan, R.; Ouimet, R. Soil organic sulfur dynamics in a coniferous forest. Biogeochemistry 2001, 53, 105-124. [CrossRef]

59. Shi, S. Eeo-Chemistry of Sulufr under Imapct by Acid Depoistion-A Case Study of Forest Ecosystem ay Mt.Lushan. Ph.D. Thesis, Nanjing Argricutural University, Nanjing, China, 2000.

60. Yu, Q. Fate of Deposited Sulfur and Nitrogen in Typical Subtropical Forest Ecosystems, Southern China. Ph.D. Thesis, Tsinghua University, Beijing, China, 2019.

61. Houle, D.; Marty, C.; Duchesne, L.; Gagnon, C. Humus layer is the main locus of secondary $\mathrm{SO}_{4}$ production in boreal forests Geochim. Cosmochim. Acta 2014, 126, 18-29. [CrossRef]

62. Mayer, B.; Feger, K.H.; Giesemann, A.; Jager, H.J. Interpretation of sulfur cycling in 2 catchments in the black-forest (germany) using stable sulfur and oxygen-isotope data. Biogeochemistry 1995, 30, 31-58. [CrossRef]

63. Mayer, B.; Prietzel, J.; Krouse, H.R. The influence of sulfur deposition rates on sulfate retention patterns and mechanisms in aerated forest soils. Appl. Geochem. 2001, 16, 1003-1019. [CrossRef]

64. Yu, Q.; Si, G.; Zong, T.; Mulder, J.; Duan, L. High hydrogen sulfide emissions from subtropical forest soils based on field measurements in south China. Sci. Total Environ. 2019, 651, 1302-1309. [CrossRef] 